\title{
Mobile Applications for Students with Dyslexia: A Systematic Literature Review
}

Ahmed Aldousari

Department of Teaching and Learning, College of Education, Washington State University

\begin{abstract}
Students with dyslexia often face many challenges in their learning process. Some of the challenges could be trying to understand the content when they lack the ability to read properly. Teachers, however, and all other professional stakeholders have a duty to find ways to help these students meet quality education and exploit their maximum potential despite their challenges. By incorporating technological solutions in the classrooms, academic challenges for learners can be reduced, ensuring that students with dyslexia get the most out of the education process. Therefore, this systematic literature review aims to explore what mobile applications are available that can be used to enhance the learning experience for students with dyslexia and what the literature says about how the overall learning experience of these students might change by providing mobile applications. Nine articles met the criteria for review and were included. The results showed that the introduction of mobile applications can effectively enhance the learning process, essentially pertaining to individuals with dyslexia. Furthermore, the various systems being developed in the form of m-learning applications are proving to be useful, especially on pre-literacy and dyslexic learning. The new developments are poised to increase students with dyslexia motivations for learning since they grant them an opportunity and avenue to make the learning process easy for them. The review concludes that there is a need for more research to determine what development components are needed to evaluate the mobile application that being used for students with dyslexia.
\end{abstract}

KEYWORDS: Mobile application, learning disability, students with dyslexia, assistive technology

Mobile Applications for Students with Dyslexia: A Systematic Literature Review

\section{INTRODUCTION}

For all students, reading proficiency is a life skill that is crucial and one that each student should acquire (Odegard et al., 2020). Lacking the ability of reading would thus reduce the individual ability to build knowledge and acquire information. Reading helps an individual to be able to understand the world around them; hence granting them the opportunity to accomplish tasks and achieve goals (Jenkins \& O'Connor, 2002). However, there are various individuals that have reading difficulties regardless of their level of intelligence or social status (Madeira et al., 2015). Essentially, this disorder is referred to as dyslexia and requires specialized attention in the early years of one's life. Specifically, dyslexia can be defined as a unique learning disturbance that is seen in one's ability to read. The disorder affects approximately $20 \%$ of the world's population (Skiada et al., 2014).

Many students in schools around the globe have not yet acquired reading proficiency due to reading difficulties that are often classified as dyslexia. In fourth grade, only $37 \%$ of the students were able to display reading proficiency as per the National Association for Educational Progress reading achievement test (NAEP, 2017). The test assesses a student's ability to read and comprehend as well as other different high-stake tests that are associated with reading achievement, reading accuracy, as well as proficiency. An individual that is having dyslexia may have issues with reading and writing even though they are intelligent or exposed to various opportunities. There are various characteristics that are common among those with dyslexia even though the disorder may vary from one individual to another. These characteristics are difficulties with the overall phonological processing, difficulty in spelling and rapid visual-verbal response.

In the modern day, there is an outburst of technology in many spheres of life (Rahim et al, 2018). Some of these digital technologies that are in existence can be utilized to assist in the learning process of those that have dyslexia. Furthermore, intervention methods are being researched all across the globe with the aim of establishing and creating assistive technology that could be used to alleviate the various effects associated with dyslexia. Today, large tracts of research are being carried out to establish how information and technology can be effectively utilized to become a learning platform that individuals with dyslexia can use to better their reading and writing experience. Essentially, mobile applications are being developed for people with dyslexia in mind, which can be effectively used by people with dyslexia. These mobile applications are meant to improve the fundamental skills of those with dyslexia such as improving their problem-solving skills, short term memory, and orthographic coding. 
Since dyslexia is neurobiological in origin, it cannot be cured, though its effects may be alleviated (Lyon \& Shaywitz, 2003). Essentially, early detection and intervention can help an individual to improve themselves and be able to eventually overcome the learning difficulties and challenges (Rahim et al., 2018). Dyslexia is mainly due to the difficulty and disability to identify or recognize the sound or shape of a given character. Mobile applications have become rampant in the day today as many people prefer using these applications to accomplish various tasks. Each day, new applications are developed and are incorporated into the everyday activities of various individuals. For instance, the 'Dyslexia Baca' is a mobile application that helps children to be able to recognize and distinguish various letters. Furthermore, the market for the various applications is also growing each day as new ideas and innovations are brought forth each day. Information technology is also being adopted in the learning process and utilized to bring forth various results (Skiada et al., 2014). Research carried out by various scholars has determined that information technology can assist in the overall learning process.

Mobile learning entails using mobile phones and mobile devices to simplify the learning process. For those that are having dyslexia disorders, mobile applications can be utilized to enhance their reading and writing experience, while at the same time alleviating the various effects associated with dyslexia (Madeira et al., 2015). Notably, the incorporation of these applications and devices to the learning environment, especially among individuals that have dyslexia, has proven to be fruitful particularly in bettering the overall learning experience of those that have this disorder. These mobile devices and applications can be effectively utilized in creating a learning environment where individuals with dyslexia make the most out of the mobile applications and devices and ultimately are able to have a fruitful experience in regard to reading and writing (Rello et al., 2012).

\section{METHOD}

\section{Search Criteria}

Three databases were used for the purpose of searching for the articles used. These databases were ERIC, WSU library, as well as Google Scholar. The keywords used for the search were mobile apps, mobile applications and dyslexia. Seven peer-reviewed research articles were chosen for the study and two dissertations. All these were from the year 2010 to the year 2019. The total research articles incorporated in the research and study were nine, seven of which were peer reviewed articles while the other two were dissertations.

\section{Selection Criteria}

For an article to be selected for the project, it had to be one that talks about dyslexia from a research's point of view. Each article had to have dyslexia as the main focus as well as the use of mobile applications for alleviating the effects of dyslexia. Essentially, there were seven peer-reviewed articles and two dissertations. The reason why the researcher made an exception and included the two dissertations was that there are not many studies about dyslexia and mobile applications, thus the dissertations were used as reference points in regard to literature that was cited from other scholarly authors. Each of these had to be English written. This means that not all articles could fit in these criteria unless it was written in English for the understanding of everyone.

\section{Data Extraction}

The data gathered from the nine studies was organized into a table that highlights the title of the article, the authors, purpose, the participants, the study design and the findings of the research. The essence of this extraction of data was to establish the various common themes in regard to the subject of study.

\section{Study Selection}

The flow chart below displays the selection process of the articles used and included in the systematic literature review. 72 articles were identified from ERIC, Google Scholar, and WSU library. Using the key words mobile apps, mobile applications and dyslexia, the articles were acquired and filtered so that nine remained which were used in the systematic literature review

\section{Selection Process Flow Chart}

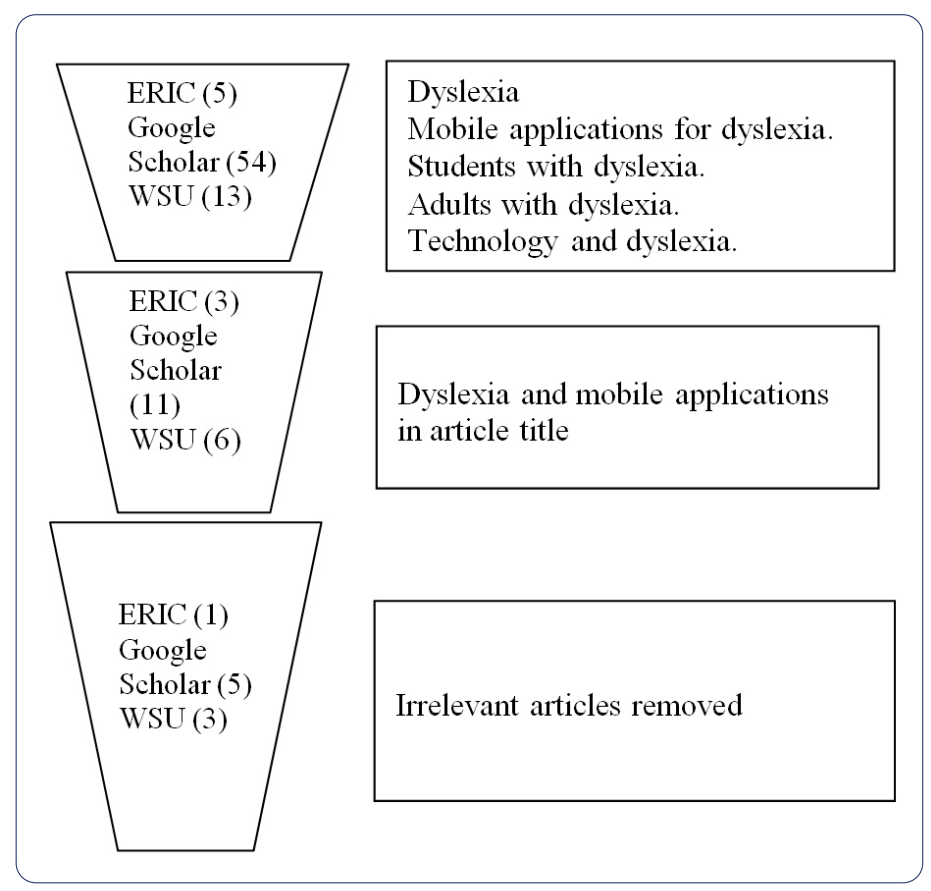


Table 1.

\begin{tabular}{|c|c|c|c|c|c|}
\hline Title & Author (s) & Purpose & Participants & Study design & Findings \\
\hline $\begin{array}{l}\text { A Mobile } \\
\text { Application } \\
\text { for Displaying } \\
\text { More Accessible } \\
\text { eBooks for People } \\
\text { with Dyslexia }\end{array}$ & $\begin{array}{l}\text { Luz Relloa, } \\
\text { GaurangKanvindeb, } \\
\text { \&Ricardo Baeza-Yatesc }\end{array}$ & $\begin{array}{l}\text { To implement a } \\
\text { mobile application that } \\
\text { helps in displaying } \\
\text { eBooks in a way that } \\
\text { is more accessible in } \\
\text { accordance with the } \\
\text { needs of the users. }\end{array}$ & $\begin{array}{l}22 \text { native } \\
\text { Spanish } \\
\text { speakers } \\
\text { diagnosed } \\
\text { with dyslexia } \\
\text { took part in the } \\
\text { study. } 22 \text { other } \\
\text { participants } \\
\text { without } \\
\text { dyslexia also } \\
\text { took part in the } \\
\text { study. }\end{array}$ & $\begin{array}{l}\text { Semi-structured } \\
\text { interviews and } \\
\text { a questionnaire } \\
\text { were used. }\end{array}$ & $\begin{array}{l}\text { Findings reveal that } \\
\text { dyslexia varies between } \\
\text { languages as well as } \\
\text { subjects. Furthermore, } \\
\text { using complicated } \\
\text { language is a key problem } \\
\text { that many people that } \\
\text { have dyslexia encounter. } \\
\text { The existing applications } \\
\text { only help in modifying } \\
\text { the design and not the } \\
\text { content and thus this } \\
\text { should be taken into } \\
\text { consideration. }\end{array}$ \\
\hline $\begin{array}{l}\text { Designing Mobile } \\
\text { Application } \\
\text { for Dyslexia in } \\
\text { Reading Disorder } \\
\text { Problem }\end{array}$ & $\begin{array}{l}\text { Siti Khatijah Nor } \\
\text { Abdul Rahim, Nur } \\
\text { HasniNasrudin, Anis } \\
\text { Zafirah Azmi, Rosida } \\
\text { Ahmad Junid, Zainab } \\
\text { Mohamed, Inilmaina Binti } \\
\text { Abdullah }\end{array}$ & $\begin{array}{l}\text { The study purposed } \\
\text { to confirm the theory } \\
\text { related to dyslexia } \\
\text { in regard to the } \\
\text { characteristics of } \\
\text { children that have } \\
\text { dyslexia and identify } \\
\text { the learning materials } \\
\text { that are effective and } \\
\text { suitable for these } \\
\text { children. }\end{array}$ & $\begin{array}{l}10 \text { students } \\
\text { with dyslexia. }\end{array}$ & Interview & $\begin{array}{l}\text { The findings of the study } \\
\text { helped obtain valuable } \\
\text { information regarding } \\
\text { the characteristics and } \\
\text { requirements which can } \\
\text { be incorporated in the } \\
\text { design of the mobile } \\
\text { application which can } \\
\text { assist the dyslexia } \\
\text { children in reading. }\end{array}$ \\
\hline $\begin{array}{l}\text { Mobile } \\
\text { application design } \\
\text { and } \\
\text { Development on } \\
\text { touch screen } \\
\text { Phones for adults } \\
\text { with dyslexia }\end{array}$ & Norman D Dambul & $\begin{array}{l}\text { The purpose of the } \\
\text { project was to create a } \\
\text { mobile application that } \\
\text { helps dyslexic adults to } \\
\text { be able to read better on } \\
\text { a touch screen phone. }\end{array}$ & 5 volunteers & Questionnaire & $\begin{array}{l}\text { The findings of the study } \\
\text { reveal that there was } \\
\text { an improvement in the } \\
\text { readability of those that } \\
\text { used the questionnaire. } \\
\text { Furthermore, the findings } \\
\text { reveal that each volunteer } \\
\text { had a specific color that } \\
\text { was suitable for them. }\end{array}$ \\
\hline $\begin{array}{l}\text { D-Lexis: Alphabet } \\
\text { Mobile Learning } \\
\text { Application for } \\
\text { dyslexia Based } \\
\text { on Slingerland } \\
\text { Methods of } \\
\text { Learning }\end{array}$ & $\begin{array}{l}\text { Nor Nadia Bt Jamal Abd } \\
\text { Nasir }\end{array}$ & $\begin{array}{l}\text { The purpose of the } \\
\text { study was to develop } \\
\text { a mobile play tool } \\
\text { that would be used } \\
\text { for learning dyslexia } \\
\text { alphabet on the basis of } \\
\text { Slingerland's approach }\end{array}$ & $\begin{array}{l}\text { The } \\
\text { participants of } \\
\text { this study are } \\
\text { young students } \\
\text { with dyslexia } \\
\text { age between } 8 \\
\text { to } 10 \text { years old. }\end{array}$ & $\begin{array}{l}\text { Interviews, } \\
\text { qualitative } \\
\text { surveys, and } \\
\text { observation }\end{array}$ & $\begin{array}{l}\text { The application developed } \\
\text { has dyslexia learning as } \\
\text { a focus and it follows } \\
\text { the various needs and } \\
\text { requirements of a dyslexic } \\
\text { patient. }\end{array}$ \\
\hline $\begin{array}{l}\text { Acceptance and } \\
\text { readiness of } \\
\text { mobile } \\
\text { Learning } \\
\text { integration among } \\
\text { teachers of } \\
\text { Dyslexic students: } \\
\text { a preliminary } \\
\text { study }\end{array}$ & $\begin{array}{l}\text { Nor Zuhaidah Mohamed } \\
\text { Zain and Murni Mahmud }\end{array}$ & $\begin{array}{l}\text { The purpose of the } \\
\text { study was to acquire } \\
\text { an understanding of } \\
\text { the readiness and } \\
\text { acceptance of mobile } \\
\text { learning integration } \\
\text { especially among the } \\
\text { teachers of students } \\
\text { with dyslexic. }\end{array}$ & $\begin{array}{l}\text { The } \\
\text { participants } \\
\text { of this study } \\
\text { consisted } \\
\text { of four (4) } \\
\text { teachers who } \\
\text { have been } \\
\text { teaching } \\
\text { mild level of } \\
\text { students with } \\
\text { dyslexia for } \\
\text { five (5) years } \\
\text { and above. }\end{array}$ & $\begin{array}{l}\text { Semi-structured } \\
\text { questions }\end{array}$ & $\begin{array}{l}\text { The possession of } \\
\text { personal mobile devices } \\
\text { can somehow grant } \\
\text { positive or negative } \\
\text { influence on the teachers } \\
\text { as they decide to integrate } \\
\text { m-learning or not to } \\
\text { integrate it. }\end{array}$ \\
\hline
\end{tabular}




\begin{tabular}{|c|c|c|c|c|c|}
\hline $\begin{array}{l}\text { EasyLexia: } \\
\text { A Mobile } \\
\text { Application for } \\
\text { Children with } \\
\text { Learning } \\
\text { Difficulties }\end{array}$ & $\begin{array}{l}\text { RoxaniSkiada, Eva } \\
\text { Soroniati, Anna } \\
\text { Gardeli\&Dimitrios Zissis }\end{array}$ & $\begin{array}{l}\text { The purpose was } \\
\text { developing a mobile } \\
\text { application that could } \\
\text { foster learning as well } \\
\text { as help children to be } \\
\text { able to improve various } \\
\text { fundamental skills. }\end{array}$ & $\begin{array}{l}\text { The } \\
\text { participants of } \\
\text { this study are } \\
\text { Five students } \\
\text { with dyslexia. }\end{array}$ & $\begin{array}{l}\text { Questions and } \\
\text { observations }\end{array}$ & $\begin{array}{l}\text { All of the students } \\
\text { preferred completing and } \\
\text { practicing the various } \\
\text { tests on a mobile device } \\
\text { and not on paper. }\end{array}$ \\
\hline $\begin{array}{l}\text { A Mobile } \\
\text { Application to } \\
\text { Improve Learning } \\
\text { Performance of } \\
\text { Dyslexic } \\
\text { Children } \\
\text { with Writing } \\
\text { Difficulties }\end{array}$ & $\begin{array}{l}\text { Rabbia Tariq* and Seemab } \\
\text { Latif }\end{array}$ & $\begin{array}{l}\text { To improve the writing } \\
\text { introductory skills of } \\
\text { children with dyslexia } \\
\text { as well as an evaluation } \\
\text { of the learning } \\
\text { performance of these } \\
\text { children to highlight } \\
\text { the various weak areas } \\
\text { of the students overall } \\
\text { learning process. }\end{array}$ & $\begin{array}{l}20 \text { students } \\
\text { with dyslexia }\end{array}$ & $\begin{array}{l}\text { Interviews and } \\
\text { literature survey }\end{array}$ & $\begin{array}{l}\text { Findings reveal that the } \\
\text { developed application } \\
\text { eases the needs of } \\
\text { students with dyslexia and } \\
\text { has helped measure the } \\
\text { progress of these students } \\
\text { over a period of time. }\end{array}$ \\
\hline $\begin{array}{l}\text { Assistive Mobile } \\
\text { Applications for } \\
\text { Dyslexia }\end{array}$ & $\begin{array}{l}\text { Jorge Madeiraa, } \\
\text { Catarina Silvaa,b, Luís } \\
\text { Marcelinoa,c*, Paula } \\
\text { Ferreiraa }\end{array}$ & $\begin{array}{l}\text { To address assistive } \\
\text { mobile application use } \\
\text { for dyslexia as well as } \\
\text { giving feedback to the } \\
\text { teacher, and students }\end{array}$ & $\begin{array}{l}\text { Portuguese } \\
\text { students aged } \\
10-12\end{array}$ & Questions & $\begin{array}{l}\text { The growth in mobile } \\
\text { technologies has created } \\
\text { a platform for the } \\
\text { development of various } \\
\text { numerous learning } \\
\text { solutions for students with } \\
\text { dyslexia and other forms } \\
\text { of specialized education. }\end{array}$ \\
\hline $\begin{array}{l}\text { 'Dyslexia Baca' } \\
\text { Mobile App } \\
\text { - the learning } \\
\text { ecosystem for } \\
\text { Dyslexic Children }\end{array}$ & $\begin{array}{l}\text { SalwaniMohd Daud } 1 \text { and } \\
\text { Hafiza Abas } 2\end{array}$ & $\begin{array}{l}\text { The main purpose of } \\
\text { the mobile application } \\
\text { 'Dyslexia Baca' is } \\
\text { to assist children } \\
\text { to distinguish and } \\
\text { recognize every letter. }\end{array}$ & $\begin{array}{l}\text { Seven } \\
\text { multimedia } \\
\text { experts }\end{array}$ & Case study & $\begin{array}{l}\text { The application assists } \\
\text { children to be able to } \\
\text { recognize and distinguish } \\
\text { letters } \mathrm{q}, \mathrm{m}, \mathrm{d}, \mathrm{p}, \mathrm{w} \text {, and } \mathrm{b} \text {. }\end{array}$ \\
\hline
\end{tabular}

\section{RESULTS}

\section{Participants}

The participants of the studies carried out were individuals that have dyslexia disorders, as well as teachers. Since the study entails identifying a mobile application that can be utilized in helping students with dyslexia to better their overall learning experience, teachers were instrumental in identifying various needs that these individuals have in regard to their learning experiences.

\section{Purpose and Study Design}

Seven of the studies highlighted the essence of mobile applications to help those who have dyslexia in their overall learning experience. These articles went in depth to reveal the overall application in regard to what it encompasses as well as what the use of this application can bring. Rello et al. (2012), for instance, revealed how a mobile application can be utilized to display eBooks for those individuals with dyslexia. Essentially, this application is an eBook reader that displays eBooks in a way that is more accessible to the user needs of the individual with dyslexia. 
Rahim et al. (2018) shed light on the designing of a mobile application that can be utilized by people with dyslexia in their everyday studies. Dambul (2014) also highlighted the importance of such an application and the advantages that it would bring for the community of adults with dyslexia. Specifically, Dambul illustrated a mobile application design on touch screen phones which adults with dyslexia can utilize in their daily routines. Abd Nasir (2013) highlighted the use of D-Lexis, an alphabet mobile learning application that can be used by those with dyslexia on the basis of the Slingerland learning methods. Skiada et al. (2014) also brought an application known as EasyLexia to light. This is essentially a mobile application that is utilized by children that have learning difficulties.

Another study by Mohamed Zain and Mahmud (2018) highlighted the issue of acceptance in relation to these technologies. Essentially, for anything to take effect, it has to be accepted into the society that it is introduced (Mohamed Zain \& Mahmud, 2018). To this end, teachers should be able to accept this new technology so that that they can take it up and utilize it in helping the students with dyslexia to enhance their understanding. Notably, teachers are instrumental in the learning process and thus cannot be left out when it comes to anything related to learning. To this end, Mohamed Zain and Mahmud (2018) illustrated the relevance of acquiring an understanding on the functionality of the mobile applications for teachers so that they can be able to use them effectively in their daily operations. In another study, Daud and Abas (2013) established that the 'Dyslexia Baca' assists children to be able to recognize and distinguish letters $\mathrm{q}, \mathrm{m}, \mathrm{d}, \mathrm{p}$, $\mathrm{w}$, and $\mathrm{b}$. the application enables these children with dyslexia to better their learning experience by distinguishing and recognizing various letters.

The purpose of the studies ranged from revealing the nature of mobile applications that can be used as well as introducing new ideas regarding new applications that can be incorporated into the learning process. The articles used were peer-reviewed and mostly qualitative in nature, which means that they provided insight and information regarding how mobile applications and technology can be utilized in alleviating the effects of dyslexia and helping those that are affected to have a better chance in their studies and learning experience. The dissertations also provided accurate information that was borrowed from other scholars in regard to dyslexia and mobile applications.

\section{Findings}

The article by Relloa et al. (2012) revealed that dyslexia varies between subjects as well as between languages. This thus means that the mobile tool developed can help people that have dyslexia to be able to read documents that are in their various mobile devices. Since dyslexia affects the individual's language, it is worth noting that accessibility can thus be approached from the text itself and not only from the layout. Many have pointed out that complicated languages are a key problem for those that experience dyslexia. Since the existing applications that have been brought forth are only capable of modifying its design and not necessarily modifying the content, researchers are on the lookout for new innovations that will be able to modify the text, which in a way will be more beneficial to those that have dyslexia.

The article by Rahim et al. (2018) established valuable input and tips that can be used in the development and design of mobile applications which are useful and instrumental to the lives of those who have dyslexia. The authors established that one way which was effective in introducing new words to the children that have dyslexia was to substitute one alphabet with another. Notably, the children enjoy this strategy and find it interesting. The study also established that grouping of alphabets was effective as it helped these children with dyslexia to remember the various alphabets that they have learned. Short stories could also be utilized in the application since the study reveals that these kinds of stories help in encouraging reading habits among the various children. The research also established that there was a need to assist individuals with dyslexia at an early age since the number of these individuals in school is steadily increasing.

One theme that stood out clearly in several articles was the place of mobile applications in regard to improving the overall reading and learning experience of students with dyslexia. These applications are useful in improving the learning experience of these individuals since they open up new ways of reading which are essential for ensuring that students with dyslexia are not left behind in regard to the learning experience. The research from several articles incorporated in the study reveals that the mobile applications have positive effects for the individuals with dyslexia and can be used to enhance their overall learning experience, thus ensuring that these individuals also get to achieve positive outcomes from learning experiences that entail reading and writing.

In their article, Mohamed Zain and Mahmud (2018) highlighted that there is an acceptance and readiness to use mobile applications in regard to help the individuals that are affected by dyslexia. The findings of their work provide significant information pertaining to the impact of m-learning which teachers perceive, as well as the impact of mobile technology in regard to learning. On a large scale, the participants welcomed the unique idea associated with integrating m-learning into the various subjects for students with dyslexia. However, the real challenge which presents itself in this sphere is creating an environment of m-learning which is engaging to the students as well as teachers. Additionally, the findings reveal that there is a challenge to boost the acceptance of teachers to assist the various students with dyslexia to be able to accept the use of mobile applications. 
Skiada et al. (2014) revealed that the first observation made was that the students preferred to practice and complete tests on their mobile devices rather than on paper which is the traditional accepted mode. The application essentially helps the students that have dyslexia to be able to keep focus and concentration, avoiding any distractions that may affect their concentration rates. Their attention is intentionally targeted on the touch screen of the device, which enhances their study. This result is an indication of the relevance and significance of technology in the learning methods of today. In another study, the students that had mild symptoms of dyslexia were able to finish their tests much faster than those who had different dyslexia levels (Abd Nasir, 2013). Furthermore, the phonological recordings helped offer educational aspects pertaining to the content, helping users to be able to recognize as well as identify and memorize various words.

The findings of the study carried out by Tariq and Latif (2016) revealed that there is a promising effectiveness pertaining to the development of applications that can advance the handwriting skills in relation to students with dyslexia and individuals. The utilization of modern mobile technology features has helped develop an application that can be used to address the diverse needs associated for children with dyslexia that encounter learning difficulties in their daily routine. The introduction of this application will offer a head start in enhancing the experience of the children particularly regarding the introductory skills of handwriting.

Madeira et al. (2015) highlighted that the vast progress seen in mobile technologies is a platform for the making of new learning solutions which can essentially be tailored for individualized, specialized education that can be modified to each student's need and specification. Primarily, this means that the needs of each student can be addressed so that they can enjoy the learning experience and not be left out by the other students. Furthermore, the specialized monitors of teachers can utilize these applications since they can rapidly collect and analyze giant tracts of data and deliver swift response in regard to the functioning of a particular student.

Daud and Abas (2013) also established that the 'Dyslexia Baca' was working to enhance the children's ability to read and recognize various letters, namely $\mathrm{q}, \mathrm{m}, \mathrm{d}, \mathrm{p}, \mathrm{w}$, and b. in this regard, it was possible to create an application that would essentially better the overall reading experience of the children with dyslexia. The modern age provided a unique platform of creating applications that would alleviate the challenge associated with dyslexia.

\section{DISCUSSION}

One common theme that emerged from the articles utilized was that mobile technology was a unique way of dealing with students with dyslexia in this modern age. Essentially, the potential of this technology cannot be underestimated as the studies analyzed have shown. Today, mobile applications that can help an individual who have dyslexia to enjoy their learning experience are in demand (Skiada et al, 2014). Many have come to the realization that these applications help the individual with dyslexia to be able to catch up in regard to their learning experience. To this end, these mobile applications are in demand and are being incorporated in various learning institutions so that they can be utilized by students with dyslexia (Dambul, 2014).

The readiness of the teachers to use these technologies was also put in question as the researchers tried to answer the question of whether teachers would accept the use of the technology as well as training regarding the use of the m-learning applications. Interestingly, the teachers revealed that they were enthusiastic about the applications since they believed that they would be instrumental in teaching students with dyslexia and bringing them to par with the rest of the class.

Specifically, these new technologies are a platform for helping students with dyslexia to be able to effectively read and write as well as understand syllables better (Tariq \& Latif, 2016). By accepting the concept of m-learning, teachers can be able to effectively apply it in the teaching process since they will have a clear understanding of the mobile application that will be useful for a specific learning purpose. Furthermore, having a clear understanding of the perspectives of students can be instrumental in integrating the m-learning technology to the setting of the classroom.

Tarik and Latif (2016) revealed that there were several limitations encountered in the study. One limitation of the mobile application was that it was developed on an Android platform. Essentially, this was recommended since it followed the industry standards and guidelines. However, this move led to a significant limitation in the sense that a large user population that does not use android was neglected. To this end, the education system developers should seek to focus on expanding on their audience by reaching out to other users that are on other interfaces such as Windows and iOS. Furthermore, the developers should also seek to integrate this application on other devices and not only on tablets.

\section{CONCLUSION}

Conclusively, the studies have established that the introduction of mobile applications can effectively enhance the learning process essentially pertaining to individuals with dyslexia. Furthermore, the various systems being developed in the form of m-learning applications are proving to be useful especially on pre-literacy and dyslexic learning. The new developments are poised to increase 
motivations for the learning of students with dyslexia since they grant them an opportunity and avenue to make the learning process easy for them. The studies that involved teachers found that the teachers are also ready to accept these new technologies since they have realized the various advantages that they can bring to the learning experience of students with dyslexia. These teachers are also ready to undergo specialized training so that they can be able to effectively teach the students with dyslexia as well as the other students in the classroom environment. However, more research is needed to evaluate the mobile application that being used for students with dyslexia, and to find out what training components are needed that could contribute to improving teacher skills on implementing m-learning applications for these students.

\section{REFERENCES}

1. Dambul, N. (2014). Mobile Application Design and Development on Touch Screen Phones for Adults With Dyslexia (Phd). University of Manchester.

2. Daud, S. M., \& Abas, H. (2013, December). 'Dyslexia Baca'Mobile App--The learning ecosystem for dyslexic children. In 2013 International Conference on Advanced Computer Science Applications and Technologies (pp. 412416). IEEE.

3. Jamal Abd Nasir, N. (2013). D-Lexis: Alphabet Mobile Learning Application for dyslexia Based on Slingerland Methods of Learning (Undergraduate). UniversitiTeknologi PETRONAS.

4. Jenkins, J., \& O’Connor, R. (2002). Early identification and intervention for young children with reading/learning disabilities. Identification of Learning Disabilities: Research to Practice, 2, 99-149.

5. Lyon, G. R., \&Shaywitz, S. E. (2003). Defining dyslexia, comorbidity, teachers' knowledge of language and reading: A definition of dyslexia. Annals of Dyslexia, 53, 1-14.

6. Madeira, J., Silva, C., Marcelino, L., \& Ferreira, P. (2015). Assistive mobile applications for dyslexia. Procedia computer science, 64, 417-424.
7. Mohamed Zain, N., \& Mahmud, M. (2018). Acceptance and readiness of mobile learning Integration among teachers of dyslexic students: A preliminary study. The International Journal Of Multimedia \& Its Applications, 10(06), 157-168. doi: 10.5121/ijma.2018.10613

8. National Association for Educational Progress. (2017). NAEP reading report card: National achievement-level results. National Center for Educational Statistics.

9. Odegard, T., Farris, E., Middleton, A., Oslund, E., \&RimrodtFrierson, S. (2020). Characteristics of students identified with dyslexia within the context of state legislation. Journal of Learning Disabilities, 53(5), 366-379. https://doi. org/10.1177/0022219420914551

10. Rahim, S. K. N. A., Nasrudin, N. H., Azmi, A. Z., Junid, R. A., Mohamed, Z., \& Abdullah, I. I. B. (2018). Designing mobile application for dyslexia in reading disorder problem. International Journal of Academic Research in Business and Social Sciences, 8(1), 628-646.

11. Rello, L., Kanvinde, G., \&Baeza-Yates, R. (2012). A mobile application for displaying more accessible eBooks for people with Dyslexia. Procedia Computer Science, 14, 226-233.

12. Skiada, R., Soroniati, E., Gardeli, A., \& Zissis, D. (2014). EasyLexia: A mobile application for children with learning difficulties. Procedia Computer Science, 27, 218-228.

13. Tariq, R., \& Latif, S. (2016). A mobile application to improve learning performance of dyslexic children with writing difficulties. Journal of Educational Technology \& Society, $19(4), 151-166$.

Citation: Ahmed Aldousari "Mobile Applications for Students with Dyslexia: A Systematic Literature Review”. American Research Journal of Humanities and Social Sciences, Vol 7, no. 1, 2021, pp. 1-7.

Copyright @ 2021 Ahmed Aldousari, This is an open access article distributed under the Creative Commons Attribution License, which permits unrestricted use, distribution, and reproduction in any medium, provided the original work is properly cited. 